\title{
ATTRIBUTE SELECTION \\ OF INDONESIAN TELEMATIC SERVICES MSMES FEASIBILITY ASSISTANCE, USING AHP
}

\author{
${ }^{a}$ Eneng Tita Tosida, ${ }^{\text {b Kudang Boro Seminar, }{ }^{c} \text { Yeni Herdiyeni }}$ \\ ${ }^{a}$ Computer Science Department, Pakuan University, Jl. Pakuan PO Box 452, Bogor \\ ${ }^{\mathrm{b}}$ Agroculture Engineering Department, IPB, Gd. Fateta lt.2 Kampus IPB Dramaga, Bogor \\ ${ }^{\mathrm{c}}$ Computer Science Department, IPB, Jl. Meranti Wing 20 Level 5, Dramaga, Bogor \\ Email : enengtitatosida@unpak.ac.id
}

\begin{abstract}
The assistance program had not absorbed optimally yet for telematics Micro Small Medium Enterprises (MSMEs). One of the reasons was the data of telematics MSME which still separated in the several institutions. This research aimed to selection of assistance feasibility attributes using Analytical Hierarchy Process (AHP) based on National Socio-Economic Survey (Susenas) data. This data attributes conformed to the criteria of assistance feasibility which was implemented among by Ministry of Cooperative, Small and Medium Enterprises (SMEs), and related institutions. The attributes involved the characteristic of technology, economics, human resources, partnerships, obstacles, prospect and other common conditions. The process of data preparation was needed involving cleaning, discretization, description and transformation of data. The AHP technique aimed to produce rankings and the value of attributes. The finding of this research showed that start-up essence and technology factors became the crucial attributes in the feasibility assessment. The other factors were the economy, human resources, partnerships and development planning. The findings of this research had given the new innovations; in addition of the scope of related substance Telematics Service MSMEs which was still studied limitedly, and the selection technique of assessment feasibility attributes based on Susenas data.
\end{abstract}

Keywords: Analytical Hierarchy Process (AHP), Data Preparation, Telematics services, Susenas. 


\section{INTRODUCTION}

The development of telematics business sector became a government attention because it was one of the national businesses priorities in developing Indonesia nowadays. The trend which had led to service products influenced trend developing in telematics sector. The specific research concerned in the effort of developing business of Indonesian telematics service was very limited. In fact, the Central Bureau of Statistics in 2012 showed the average of GDP telematics sector in Indonesia each year had increased $18.2 \%$, and telematics services business grew $4 \%$ [1].

The Scope of telematics services business in Indonesia was based on Indonesian Standard Industrial Classification (ISIC) by The Ministry of Industry Regulation 6/M.Ind/PER/7/2011. MSMEs (67\%) is still dominated by low level of innovation, it's only around $15-20 \%$. The Status of investor in telematics service business is still dominated by non-facilities (90\%) [1]. It showed that the MSME of telematics services business in Indonesia generally is still needs empowerment, such as by assistance programs.

The Indonesian Ministry of Cooperatives and SMEs have empowerment programs in the form of financial assistance grants for MSMEs. This program was based on the actual conditions of businessmen in Indonesia that was dominated by micro enterprises, which reached $98.77 \%$ [2]. The realization of this assistance program was able to be absorbed by 3860 MSMEs in 2013 (from the total of 57.18 million MSMEs), but the MSMEs who engaged in the telematics sector was only $4.7 \%$.

One of the low absorptive capacity assistance factors was the spread of the data across multiple institutions that were hard to be integrated. The initial identification efforts to increase the absorption of assistance programs for telematics services MSMEs can be conducted by utilizing a centralized data such as the data from National Socio-Economic Survey (Susenas) - Central Bureau of Statistics $(B P S)$. These data have attributes that are relevant to the system of assistance feasibility assessment for MSMEs, but the system of assistance feasibility for MSMEs in The Ministry of Cooperatives and SMEs had not been supported yet by determination of priorities or the ranking of assessment attributes. It can reduce the objectivity of assessment.

Weighting process based on the multiple attributes pattern can be done through various approaches, one of them is AHP. Critical Success Factors (CSF's) of high-Tech SME's in Iran were identified by Group AHP model [3]. AHP has also been used by [4], to select the development strategies of small enterprise. Identification and evaluation process of Critical Factors (CFs) of innovation management by technology transfer has been done by AHP approach [5] and resulting a strategic conceptual framework.

The attributes of assistance feasibility assessment for telematics services MSMEs include the characteristic of technological, economics, human resources, partnerships and other common conditions. The using of those attributes (aspects of labor and economy) had been used by [6] and [7], in the process of credit assistance for SMEs of technological base. The process of assistance feasibility assessment to the start-up technology base agents in Korea also used economic indicators attributes and characteristics of the company [8];[9]. Education attributes in the owner profile, can be used for assessment. It mentioned in the research conducted by [10] informed that the education both owner and labor would impact on MSMEs business development furthermore this telematics services business related closely to innovation. The ability to establish partnerships is very crucial to support MSMEs in the development of the business, it was conducted to be able to support its limitations [11].

This research proposed the development model of the assistance feasibility attribute selection for Indonesian Telematics Services MSME's using AHP approach, which capable to produce attributes ranked and weighted. The result of this research can be used to assistance feasibility assessment systems which include the whole data in Indonesia, so that it can be used to analyze MSMEs condition in every province and type of assistances given to the right target.

\section{METHODS}

This research was conducted through a methodology presented on Figure 1. Modeling process was begun by data preparation, because 
Susenas data was large and complex (containing from 21 attributes).

\section{Cleaning Data}

The attributes which were involved in this research consisted four items numeric data attributes, and 17 categorical data attributes. The determining collaborative AHP technique which is collaboration of quantitative and qualitative was suitable to determine collaboration attributes.

The cleaning of telematics service business based on National Socio-Economic Survey 2006 was conducted by admission filling using mean value (numerical data) and modus (categorical data). The further data cleaning will be conducted by deleting the inconsistent data with outlier related to Law number 20 of 2008 causing reduction data from 12541 to 8798.

\section{Discretization of Numerical Data}

The process of discretization in Table 1 was conducted for continued numerical data, based on the Law Number 20 of 2008 related to MSMEs (relating value attributes of Cost and Assets attribute). Based on the law, Addedvalue and Cost attribute were integrated to Sale attribute. The number of labor MSMEs discretization based on BPS 2013. Remuneration attribute was reduced because it has a high correlation with the number of labor $(r=0.7)$.

\section{Data Transformation}

The data transformation was conducted by giving code to categorical data, using consistent numerical code; $1,2,3$, etc. the way of this data transformation was conducted to all categorical attributes, except for the year operations attributes which conducted based on Table 2 .

The result of the first transformation would be confirmed to the related resources used determining the level of assistance feasibility benefit. All of the attributes would be ordinal data, with the sequence is 1 as the data that is most prioritized for getting assistance. Assumptions and some of the considerations were used in these ordinal data usage, so that the selection process attribute using AHP being more valid based on the conditions of the National Socio-Economic Survey data on 2006.

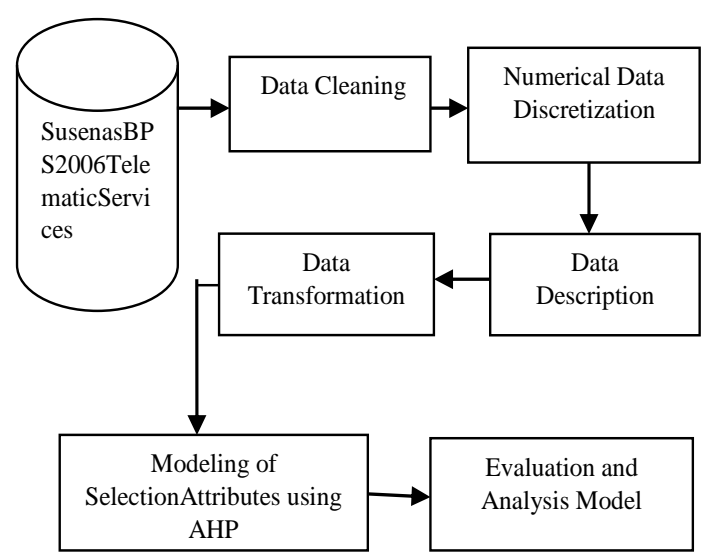

Figure 1. Research Methodology

\section{Data Description}

The description of the data was conducted through reviewing the frequency of occurrence data on each attribute to determine the distribution pattern that occurred. The examples of description related provinces attribute showed that the existence of Indonesian Telematics Services MSMEs until 2006 concentrated Yogyakarta having the highest distribution (15.28\%). Respectively West Java (12.88\%), East Java (11.59\%), Jakarta $(10.35 \%)$ and the lowest distribution is the province of Papua $(0.34 \%)$. This condition indicated that the distribution of telematics services provider at the time it is still not

Table 1. Classification of MSME based on Law No. 20 of 2008

\begin{tabular}{|c|c|c|c|}
\hline Attribute & Micro & Small & Secondary \\
\hline $\begin{array}{l}\text { Wealth } \\
\text { (Total } \\
\text { Assets)* }\end{array}$ & $\begin{array}{l}<50 \\
\text { Million }\end{array}$ & $\begin{array}{l}50 \\
\text { Million } \\
\text { s.d 500 } \\
\text { Million }\end{array}$ & $\begin{array}{l}500 \text { Million } \\
\text { s.d } 10 \text { Billion }\end{array}$ \\
\hline $\begin{array}{l}\text { Sales per } \\
\text { Year* }\end{array}$ & $\begin{array}{l}<300 \\
\text { Million }\end{array}$ & $\begin{array}{l}300 \\
\text { Million } \\
\text { s.d 500 } \\
\text { Million }\end{array}$ & $\begin{array}{l}\text { 2.5 Billion } \\
\text { s.d } 50 \text { Billion }\end{array}$ \\
\hline $\begin{array}{l}\text { Labor } \\
\text { (person)* } \\
*\end{array}$ & 1 s.d 4 & 5 s.d 19 & 20 sd 99 \\
\hline Code & 1 & 2 & 3 \\
\hline
\end{tabular}

*Sources of LawNo.20of 2008 on MSMEs

** Source BPS (2013) 
evenly distributed. There is a possibility changes in the distribution pattern for the last 9 years, and it was indicated by the level of household access to computers and the internet which were relatively distributed in all provinces with a range of $16.07 \%-30.4 \%$ (computer access) and $14.1 \%-28.3 \%$ (internet access) [12]. The access of computers and internet is one of the products and telematics services (which can be used as an indicator to increase the production of telematics sector).

The other general descriptions were indicated through the educational performance of owner of telematics services MSMEs. Telematics services MSMEs is one of the technological innovation that is the fastest changing, and one of the factors that contributed in the innovation is the condition of human resources, including the owner of business generally on MSMEs which is also direct employees [13][14].

\section{RESULT AND DISCUSSION}

Attribute selection model of assistance feasibility arranged through the hierarchy as in Figure 2. The stakeholders were involved in this research was came from academic field of Computer Science, related regulators MSME (Head of the Institute of Entrepreneurship, Ministry of Coop-SME), the regulator related to the implementation of business telematics (Head of R \& D of Post and Informatics, Ministry of Information and Communication). The interview process referred to the selection of interesting degree of the twentieth giving attributes for Telematics Services MSMEs, which was assessed by pairwise comparisons using assessment scale by Linkert [15].

The processing data from interviews conducted using Expert Choice Software 2000 uses EigenVector (EV) methods. EV method refers to the equation:

$$
\operatorname{det}(A-\lambda I)=0
$$

For each eigenvalue $\lambda$ we have

$$
(A-\lambda I) x=0
$$

Where $\mathrm{x}$ is eigenvector associated with eigenvalue $\lambda$.

The process of aggregation was conducted using a Geometric Mean which refer to the formula:

$$
\left(\Pi_{i=1}^{n} x_{i}\right)^{\frac{1}{n}}=\sqrt[n]{x_{1} x_{2 \ldots}} x_{n}
$$

Table 2. Data Transformation of Operations Year Attribute

\begin{tabular}{lclc}
\hline Attribute & Year & Category & Code \\
\hline Year of & 2004, & $\leq 3$ years & 1 \\
operation & 2005, & & \\
& 2006. & & \\
& $<2004$ & $>3$ years & 2 \\
\hline
\end{tabular}

Table 3. The weight ofthe interests of attributes No

Attribute

EV Value

\begin{tabular}{lcl}
\hline 1. & Years of Operation & 0.152 \\
\hline 2. & Computer Users & 0.146 \\
\hline 3. & Internet Users & 0.115 \\
\hline 4. & Type of business & 0.066 \\
\hline 5. & Sources of Capital & 0.051 \\
\hline 6. & Total Assets & 0.050 \\
\hline 7. & Sales per year & 0.049 \\
\hline 8. & MSME distributions in & 0.046 \\
& prov & 0.042 \\
\hline 9. & Legal entity & 0.036 \\
\hline 10. & Amount of labor & 0.034 \\
\hline 11. & Edication owner & 0.031 \\
\hline 12. & Cooperative member & 0.029 \\
\hline 13. & Partnership & 0.028 \\
\hline 14. & Difficulties & 0.022 \\
\hline 15. & Been Assisstanced & 0.021 \\
\hline 16. & BeenTrained & 0.018 \\
\hline 17. & Marketing & 0.017 \\
\hline 18. & Expanrion plan & 0.016 \\
\hline 19. & Conditionsthan3months & 0.014 \\
\hline 20. & Business prospect & \\
\hline
\end{tabular}

Then the other further process would be processed by finding the aggregate $\mathrm{EV}$, until obtaining ranked of importance attributes.

The results of weighting and ranking for attributes selection of Telematics Services MSMEs assistance feasilibity were presented in Table 3.

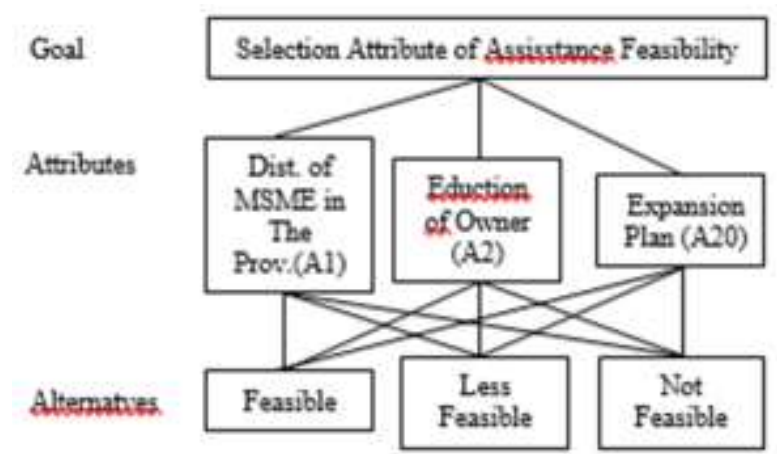

Figure 2. Hiearchycal Model 


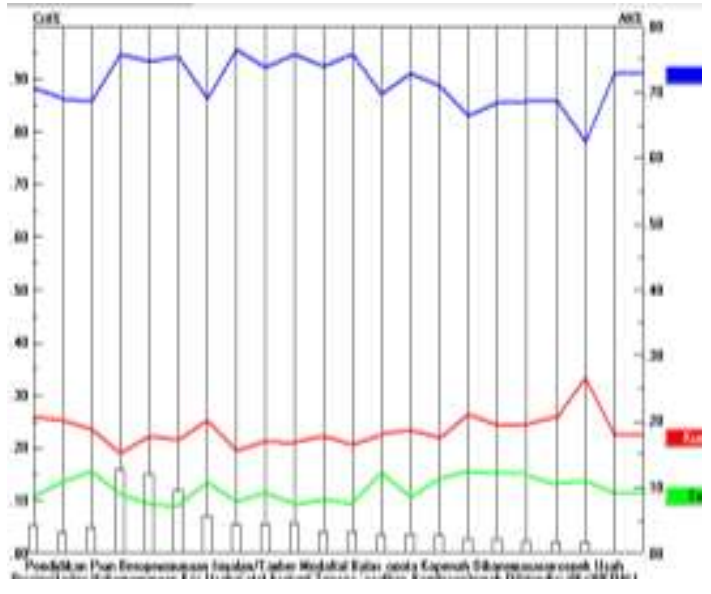

Figure 3 . The sensitivity performance analysis

This models produce Consistensy Ratio (CR) value of 0.08 . This shows that the model is quite consistent. The sensitivity performance of attributes selection of telematics services MSMEs assistance feasibility model through AHP shown in Figure 3. It was found that the order of attribute weights are related technological character, the character of the economy, human resources, partnerships and business prospects. Based on Figure 3 the main sequence has a high degree of interest to reach $90 \%$ of average.

The major of feasibility was on the attributes of Year Operation. It was in line with the Ministry of Cooperative and SMEs program [9] who prefer the kind of start-up for priority in obtaining assistance. The other important attributes are the use of internet and computers, it was the primary device in the operations of MSME telematics services. The sales per year and source of capital became the other important attributes in assistance feasibility. It was in line with Ministry of Cooperative and SME also Ministry of Communication and Telecommunication planning, they would enforce monitoring sales development for MSMEs that received government assistance.

Based on the gradient sensitivity analysis to the major attributes (the Year of Operation, Use of Internet, Computer Use, and sources of capital - presented on Figure 4) shows that the higher value of the attribute so that the assistance feasibility would be lower (blue block: Feasible, red blocks: Less Feasible, and green blocks: Not Feasible). The close similar

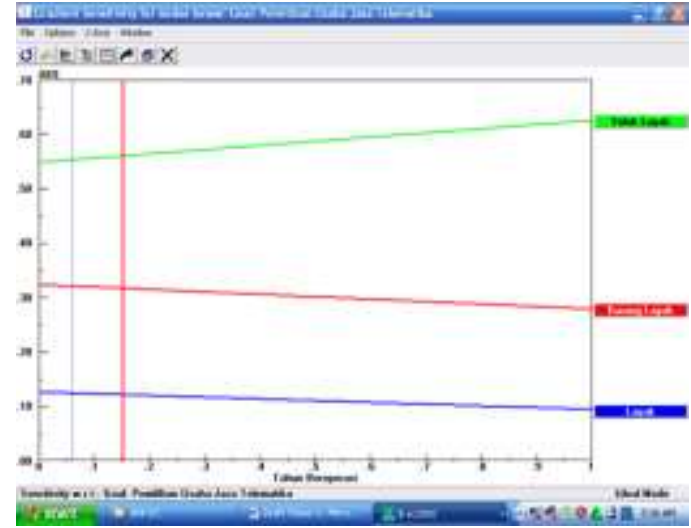

Figure 4. Proportionally gradient pattern

gradient pattern presented by other attributes except for attributes of Owners Education, Business Type, Difficulty, and Business Prospects. The Different gradient pattern presented the opposite condition (Figure 5). If the value of the four attributes is increase, so the level of assistance feasibility will be higher.

The gradient analysis results can be analyzed in more detail through the correlation between attributes through the two-dimensional sensitivity analysis. There are three patterns of correlation that was identified in this case (showed in Figure 6,7 and 8).

The first pattern of mutually reinforcing correlation between two attributes and affected higher feasibility level. This pattern indicated on the correlation between attributes of Education Owners, Difficulties, Type of Business and Business Prospects. Figure 6. presented the correlation between Owners Education and Difficulties attributes. This pattern was also formed among these four attributes, which differ only in the degree of importance.

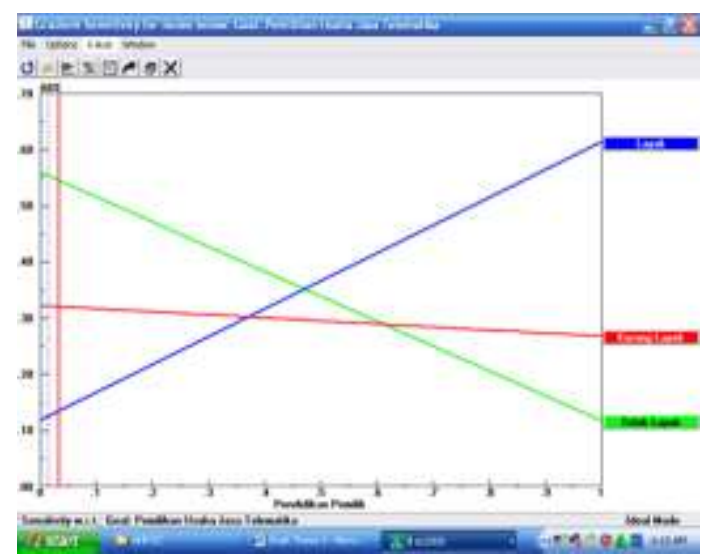

Figure 5. Inversely gradient pattern 
The MSMEs owner who has high education is expected to be a motivator for the development of telematics services MSMEs. It was in line with [13];[14] that for type of services telematics business were closely related to the level of innovation and high technology, so that the development needed to encourage through owner education (both formal and informal) which generally acts as well as workers. Type of business attribute was identified through the development of telematics services based on the rate of business growth [16]. If the rate of business is higher, so that business is more worthy to achieve the assistance. Similarly to business prospects and the level of difficulty which is perceived to be an important factor in identification of the major difficulties which was owned by the MSMEs. This kind was related to the business prospects that improved along with social change in Indonesia into the use ICT product [11].

The second correlation pattern is a pattern of correlation which indicated that the feasibility level which is higher in line with the lower value from two attributes mentioned. This pattern occurred in the correlation between the attribute of MSMEs distribution in the province with almost attributes, except the attribute of Owners Education, Difficulty, Type of Business and Business Prospects. One of the descriptions of this type was presented on Figure 7.

The feasibility assistance of telematics services MSMEs needed to be expanded in the provinces which had the lowest distribution of MSMEs. It was conducted to get result in the equity and range expanding of services by MSMEs, so that the public is increasingly served by those policies. The other strengthening was conducted through MSMEs with the type of the lowest legal entity. The government also has important role in structuring MSMEs institutional which may not be approached individually. Therefore, the program of structuring institutional for MSMEs was conducted through a group approach, one of them through the legal form of a cooperative group [2].

The duration of the MSMEs operation would be important to be assessed in this assistance feasibility, since it related to government efforts to encourage starter-up improve to be micro business.

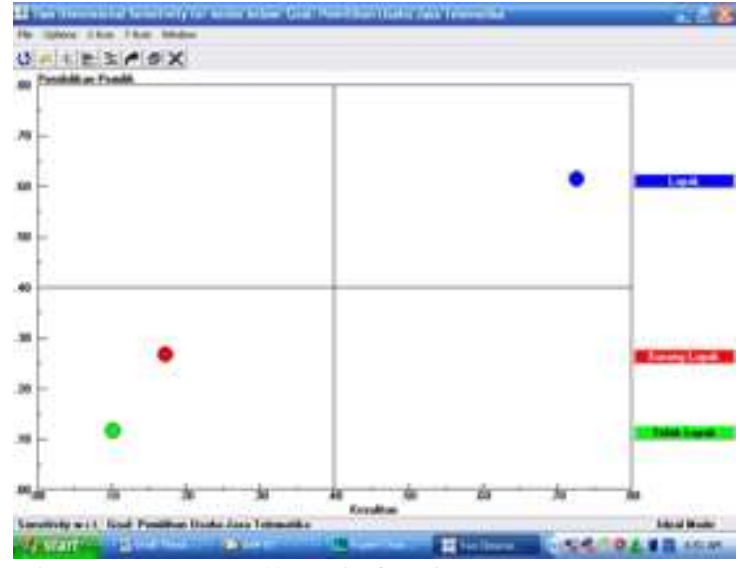

Figure 6. Mutually reinforcing pattern

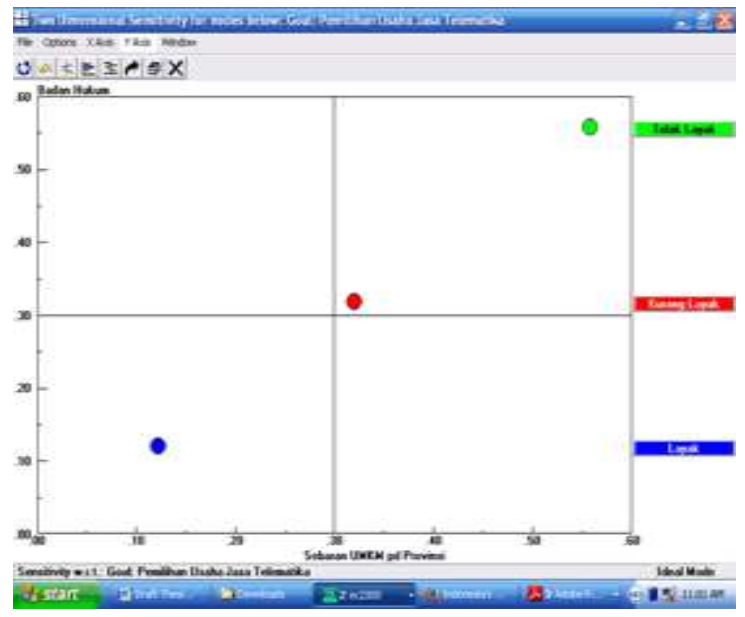

Figure 7. The patterns are mutually weaken but higher levels of feasibility

Therefore, the lower of MSMEs duration operation and is supported by other conditions based on attribute ratings, so that it will be more feasible to be given assistance. Related to this case, for the use of computers and the internet attributes, as a major tool in the operational of MSMEs telematics services, in additions the lower of using them so that the assistance feasibility be higher.

The lower of capital resources represented a higher feasibility. It was also described by the pattern of correlation between the distributions of MSMEs in the province with source of capital. The lower of MSMEs distribution in the province and the lower capital owned by MSMEs, it will get higher assistance feasibility. Low of capital often became an obstacle to the development of MSMEs [17].

The problem of absorbability financing was still low and it also related to the problem of socialization program. The involvement of the community or association is expected to 
connect this problem through partnerships and cooperative. Partnerships and cooperative membership became one of the proven ways to be able to give the chance to increase the competitiveness of MSMEs [18]. The partnerships and cooperatives are also expected to increase the interest of MSMEs Telematics Services in applying entrepreneurial mindset [19].

Based on Telematics services MSMEs data (Susenas 2006) that did partnership are still very low $(5.42 \%)$, where as the cooperative membership is relatively high, reaching 45.79\%. Partnerships and cooperative membership became one of the proven ways to be able to give the chance to increase the competitiveness of MSME [18]. The lack of partnership lead to monopoly, thus narrowing the market share and inefficient management of MSME [17].

The involvement of only governments is not enough to overcome the various problems occurred in MSMEs. According to [20] it was required contribution of universities, the private sector and community groups who are members of association or other community to support the development of MSMEs. So that the power of innovation and the creation of MSME Services Telematics can continue dynamically in accordance with its development.

Environmental policy is in line to the policy of the Master Plan for the Acceleration and Expansion of Economic Development (MP3EI) 2011-2025 which carried one of the programs the creation of the Science \& Technology Park (STP) [21].

The presence of STP are expected to improve the quality and quantity of training programs for MSMEs. This condition is very different when compared with the condition in 2006.

The results of 2006 showed that MSMEs Telematics Services who had received training assistance is still very low at only $11.09 \%$. But in this research cannot be compared current conditions, due to the willingness of the next National Socio-Economic Survey data are being prepared for implementation in 2016.

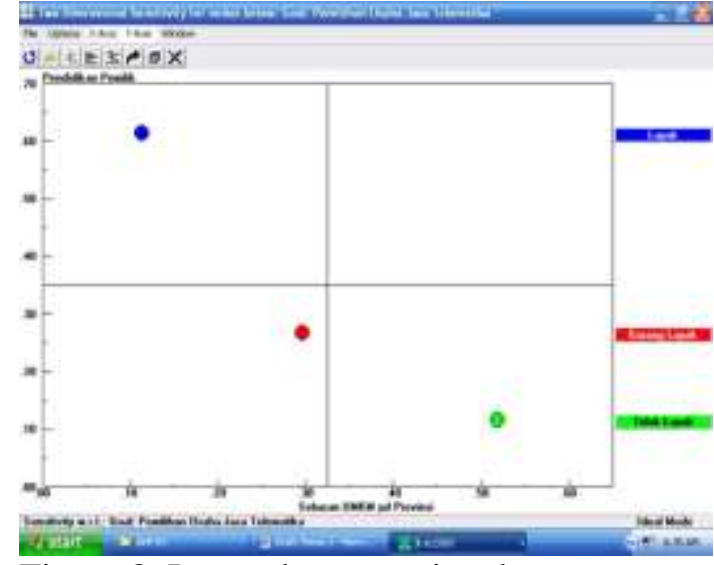

Figure 8. Inversely proportional pattern

The global competition which was faced by Indonesian MSMEs Telematics Services was getting striker, with the Asian Economic Community (AEC). If the conditions of MSMEs management of Telematics services were not managed well, it would affect the economic condition of MSMEs, which are directly related to the sales level attributes, ownership of assets, and the contribution of employment. The level of feasibility will be higher if the rate of sales, asset ownership and the number of workers was getting lower. Based on the level of sales, assets, and the number of workers of MSMEs Telematics services are still dominated by micro enterprises $(91.49 \%, 66.99 \%$ and $92.55 \%)$. in generally MSMEs in Indonesia is still dominated by micro-enterprises that have not been worthy to run the business and bankable (70\%). Referring to these conditions, the government rolled out various assistance programs including the program Empowerment of Micro Business and the National Program for Community Empowerment / PNPM [21].

The Strategic programs related to these include: providing capital for micro entrepreneurs and female entrepreneurs through cooperatives micro rural and urban areas with the status of a grant, and funding for start-up [2]. The strategic actions were not reserved for micro and telematics services, but the condition could be optimally utilized to be creative works of telematics services that promote local wisdom in their respective regions. The strategic activities rolled out in an integrated manner with the activities of the continuous training [13] to increase the competencies of actors start-ups or telematics services MSMEs. It was expected to be able to address the 
challenges related to the independence of entrepreneurs in facing global competition.

The reinforcement competencies for MSMEs Telematics services is not only for the types of technology telematics services which was offered but also the competence involved managerial competence [17]) including in the records management, finance and accounting [20]. There by training program assistance comprehensively was needed by SMEs Telematics Services in developing their business prospects. Prospects SMEs Telematics services were closely related to the economic situation [22] among locally, nationally and regionally. Therefore, various programs and strategic activities initiated by stakeholders needed to be strengthened by the existence of regulations that supported the creation of an independent SME Telematics services and highly competitive.

The final pattern was correlation pattern between inversely proportional attributes. This pattern was found in the correlation between 16 attributes which included in the second pattern to the attributes of educational owners, difficulties, types of business and business prospect. If the distribution of MSMEs is lower in the current province and the MSMEs educational owners level is higher, the level of assistance feasibility will be higher too (Figure 8). The same pattern of these, presented for the correlation between the distribution of MSME in the province and others 15 attributes with Difficulties, Type of Business and Prospects attribute.

Considering the result of this study, AHP attribute selection model can be used as an introduction of decision making, related

\section{REFERENCES}

[1] Tosida ET, Maryana S, Thaheer H. The Potencies of Indonesian Telematic Services Enterprises Group. National Conference of Information, Communicatin \& Management Proceeding. Bina Darma University, Palembang, August, 2014.

[2] Deputy of Finance. Policy Development and Empowerment Program for Cooperation SME's in Financing Sector. Ministry of Cooperation and SME's. 2014. feasibility of assistance program. Construction of Decision Support System (DSS) involving these attributes would be simpler, and it is expected to be more accurate. This will be an important point for decision makers.

\section{CONCLUSION}

The AHP attribute selection model with CR value 0.08 can be used as a reference for making decision to asses assistance feasibility for MSMES of Telematics Services based on Susenas 2006. Attribute rank includes consecutively the character of technology, economics, partnerships, human resources and business prospects which are validated by stake-holders. The advantages of this model is based on centralized data, so it can overcome the decision segmentation because of start-up data and MSMEs of Telematics services which are spread in several institutions. This model can be used by the aid agency in making decision, it is also useful for businessment to identify and prepare the character business which still need reinforcement and assistance.

The implementation of this model is very significant to develop Decision Support System (DSS) of assistance feasibility assessment for MSMEs of Telematics Services. The development of the DSS will become invention, because data base used is different from the previous system, which is dominated by assessment experts. This system will be more accurate decisions, because it is in line with the government program that will implement in Susenas 2016.

[3] Sadeghi A, Azar A, Rad RS. Developing a fuzzy group AHP model for prioritizing the factors affecting success of High-Tech SME's in Iran : A case study. ProcediaSocial and Behavioral Scieces 62 (2012) 957-961. Elsevier, doi: 10.1016/j.sbspro.2012.09.163.

[4] Erdil A, Erbiyik H. Selection Strategy via Analitic Hierarchy Process : An Application for a Small Enterprise in Milk Sector. Procedia-Social and Behavioral Sciences $195 \quad$ (2015) 2618-2628. 
Elsevier,doi:

10.1016/j.sbspro.2015.06.463.

[5] Kumar S, Luthra S, Haleem A, Mangla SK, Garg D. International Strategic Management Review 3 (2015) 24-42. Journal http://dx.doi.org/10.1016/j.ism. 2015.09.001.

[6] Sohn SY, MoonTH, Kim S. Improved Technology Scoring Model for Credit Guarantee Fund. Expert with Application 28 (2005) 327-331. Elsevier.

[7] Sohn SY, KimS, Moon TH. 2007. Predicting the Financial Performance Index of Technology Fund for SME using Structural Equaton Model. J. Expert with Application 32 (2007) 890-898. Elsevier.

[8] Kim HS, Sohn SY. Support Vector Machines for Default Prediction of SMEs Based on Technology Credit. European Journal of Operational Research 201 (2010) 838-846. Elsevier.

[9] Sohn SY, Kim JW. Decision Tree-based Technology Credit Scoring for Strart-Up Firms : Korean Case. J. Expert Systems with Applications 39 (2012) 4007-40112. Elsevier.

[10] McGuirk H, Lenihan H, Hart M. Measuring the Impact of Innovation Human Capital on Small Firms Propensity to Innovative. J. Research Policy 44 (2015) : 965-976. Elsevier.

[11] Marcelino-Sadaba S., Perez-Ezcurdia A, Lazcano AME, Villanieva P. 2014. Project risk Management Methodology for Small Firms. International J. of Project Management 32 (2014) 327-340. Elsevier.

[12] Kemenkominfo. Indicators Survey Handbook on Access and Use of ICT in Households. 2015.

[13]McGuirk H, Lenihan H, Hart $M$. Measuring the Impact of Innovation Human Capital on Small Firms Propensity to Innovative. Research Policy 44 (2015) : 965-976. Elsevier.
[14] Wawan D, Prasetio EA, Ratnaningyas S, Herliana S, Cherudin R, Aina Qorri, Bayuningrat RH, Rachmawaty E. Moderating Effect of Cluster on Firms Innovation Capability and Business Performance : A Conceptual Framework. Procedia-Social and Behavioral Science 65 (2012) 867-872. Elsevier.

[15] Marimin dan Magfiroh. Application Techniques Decision making in Supply Chain Management. IPB Press Bogor. 2011.

[16] Lee H, Lee S, Byungun Y. 2011. Technology Clustering Based on Evolutionary Patterns : The Case of Information and Communications Technologies.J. Technological Forecasting \& Social Change, Vol. 78. (2011) 953-967. Elsevier.

[17] Hafsah MJ. The Effort of SME's Development. Infokop Journal, No. 25, Tahun XX, 2004. Smecda..ejournal.unsri. ac.id/index.php/jsi/article/.../718/260.

[18] Bapeda Banyuwangi. Role of Cooperatives in supporting the development and strengthening of SMEs in Banyuwangi Regency. 2013. http:// www.bps.go.id/index.php/publikasi/1083.

[19] Afiah NN. The Role of Entrepreneurship in Strengthening Indonesian SME's to Facing the Global Financial Crisis. Paper presented at Research Day, Accounting Development Centre, Department of Accounting, Padjadjaran University. 2009.https://scholar.google.co.id/scholar? $\underline{h l=i d \& q=\ldots . . \text { al\&btn } G}=$.

[20] Ediraras DT. Accounting and SME's Performance. Economic Business Journal, No. 2, Vol. 15, August 2010. ejournal.gunadarma.ac.id/index.php/ekbis larticle/view/331/272.

[21]Soenarso Wisnu S, Nugraha D, Listyaningrum E. Development of Science and Technology Park (STP) in Indonesia to Support Innovation-Based Regional Economy: Concept and Early Stage Development. World Technopolis Review 
106 Jurnal IImiah KURSOR Vol. 8, No. 2, Desember 2015, hal 97-106

(WTR). Volume 2, Issue 1, 2013,pp.3242.World Technopolis Association. DOI : 10.7165/wtr2013. 2.1.32.

[22] Ju Y, Jeon SY, Sohn SY. Behavioral technology credit scoring model with time-dependent covariates for stress test.
European Journal of Operation Research, 242 (2015) 910-919. Elsevier. http://dx.doi.org/10/1016/j.ejor.2014.10.0 54. 